UDC 636.4:591.11

\title{
LIPID METABOLISM IN THE LYMPHOCYTES OF WEANED PIGLETS AFTER ADMINISTRATION OF LIPOSOMAL DRUG «VITARMIN»
}

\author{
N. Z. Ohorodnyk', O. I. Vischur', K. B. Smolyaninov', O. V. Holubets ${ }^{2}$, R. A. Holubets ${ }^{2}$ \\ ohorodnyk@inenbiol.com.ua
}

${ }^{1}$ Institute of Animal Biology NAAS,

38 V. Stus str., Lviv 79034, Ukraine

${ }^{2} \mathrm{SE}$ «Ukrmetrteststandard»,

4 Metrological str., Kyiv 03143, Ukraine

The influence of the liposomal drug «Vitarmin» on composition of separated classes of lipids and fatty acid profile the lymphocytes of piglets after weaning are presented in the article. The value of certain classes of lipids in the lymphocytes of blood of piglets was determined by thin layer chromatography and fatty acid composition of lipids by capillary gas-liquid chromatography.

On the $10^{\text {th }}$ day of the weaning piglets from sows, it was observed a significant increase of the content of phospholipids, reducing the content of non-esterified fatty acids and the increase of saturated fatty acids content accompanied with the decline of unsaturated fatty acids. The parenteral administration to the piglets a liposomal drug that contains vitamins $A, D_{3}, E$, L-arginine, zinc, selenium, cobalt and magnesium two days before weaning causes the increase of phospholipids content in blood lymphocytes of at the $5^{\text {th }}$ day after weaning. Reduction of saturated fatty acids and increase of unsaturated fatty acids occurred mostly at the expense of long-chain polyunsaturated fatty acids. The weaning of piglets leads to changes of lipid metabolism in the organism, as evidenced by changes in fatty acid composition of lipids in piglets blood lymphocytes. However, application of complex liposomal drug causes adjusting influence on the content of separate classes of lipids and fatty acid profile of lymphocytes of blood of piglets after weaning them from sows.

\section{Keywords: PIGLETS, WEANING, LIPOSOMAL DRUG, CLASSES OF LIPIDS, FATTY ACID COMPOSITION OF LYMPHOCYTES.}

\section{МЕТАБОЛІЗМ ЛІПІДІВ У ЛІМФОЦИТАХ КРОВІ ПОРОСЯТ ЗА УМОВ ВІДЛУЧЕННЯ І ДІЇ ЛІПОСОМАЛЬНОГО ПРЕПАРАТУ «ВІТАРМІН»}

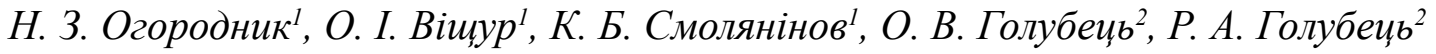 \\ ohorodnyk@inenbiol.com.ua
}

${ }^{1}$ Інститут біології тварин НААН, вул. В. Стуса, 38, м. Львів, 79034, Україна

2ДП «Укрметртестстандарт», вул. Метрологічна, 4, м. Київ, 03143, Україна

У статті наведено результати досліджень щьодо впливу ліпосомального препарату «Вітармін» на співвідношення окремих класів загальних ліпідів та жирнокислотний склад лімфочитів крові поросят за умов їх відлучення. Співвідношення окремих класів ліпідів у лімфочитах крові поросят визначали методом тонкошарової хроматографії, а жирнокислотний склад ліпідів - методом капілярної газорідинної хроматографії.

Відлучення поросят від свиноматок призводить до вірогідного зростання на 10-ту добу вмісту фосфоліпідів у лімфочитах крові та зниження неестерифікованих жирних кислот (НЕЖК), викликає збільшення вмісту насичених жирних кислот на фоні зниження ненасичених жирних кислот. Парентеральне введення поросятам за дві доби до відлучення ліпосомального препарату, що містить вітаміни А, $D_{3}, E, L$-аргінін, Цинк, Селен, Кобальт та Магній, спричиняє збільшення вмісту фосфоліпідів у лімфочитах крові на 5-ту добу після відлучення. При цьому зафіксовано зменшення сумарної кількості насичених жирних кислот й зростання ненасичених жирних кислот, яке відбувалось в основному за рахунок довголаниюгових поліненасичених жирних кислот. Відлучення поросят від свиноматок призводить до порушення метаболізму ліпідів у їхньому організмі, про щяо свідчать зміни жирнокислотного складу ліпідів у лімфоцитах крові поросят. Водночас, застосування комплексного ліпосомального препарату 
спричиняє коригувальний вплив на вміст окремих класів ліпідів та жирнокислотний спектр лімфочитів крові поросят за умов їх відлучення від свиноматок.

Ключові слова: ПОРОСЯТА, ВІДЛУЧЕННЯ, ЛІПОСОМАЛЬНИЙ ПРЕПАРАТ, КЛАСИ ЛІПІДІВ, ЖИРНОКИСЛОТНИЙ СКЛАД ЛІМФОЦИТІВ

\title{
МЕТАБОЛИЗМ ЛИПИДОВ В ЛИМФОЦИТАХ КРОВИ ПОРОСЯТ В УСЛОВИЯХ ОТЬЕМА И ПРИ ДЕЙСТВИИ ЛІИПОСОМАЛЬНОГО ПРЕПАРАТА «ВИТАРМИН»
}

\author{
Н. 3. Огородник ${ }^{1}$ О. И. Вищур ${ }^{1}$, К. Б. Смолянинов ${ }^{1}$, О. В. Голубей ${ }^{2}$ Р. А. Голубей \\ ohorodnyk@inenbiol.com.ua
}

${ }^{1}$ Институт биологии животных НААН, ул. В. Стуса, 38, г. Львов, 79034, Украина

2ДП «Укрметртестстандарт», ул. Метрологичная, 4, г. Киев, 03143, Украина

В статье приведены результаты исследований влияния липосомального препарата «Витармин» на соотношение отдельных классов общих липидов и жирнокислотный состав лимфоцитов крови поросят в условиях их отъема. Соотношение отдельных классов липидов в лимфочитах крови поросят определяли методом тонкослойной хроматографии, а жирнокислотный состав липидов - методом капиллярной газожидкостной хроматографии.

Отъем поросят от свиноматок приводит к достоверному повышению на 10-е сутки содержания фосфолипидов в лимфочуитах крови и снижению неэстерифицированых жирных кислот (НЭЖК), вызывает увеличение содержания насыщенных жирных кислот на фоне снижения ненасыщенных жирныл кислот. Парэнтеральное введение поросятам за двое суток до отъема липосомального препарата, содержащего витамины $A, D_{3}$, E, L-аргинин, Цинк, Селен, Кобальт и Магний, приводит к увеличению содержсания фосфолипидов в лимфоцитах крови на 5-е сутки после отъема. При этом зафиксировано снижение суммарного количества насыщенных жирных кислот и повышение ненасыщенных жсирных кислот, которое происходило, в основном, за счет длинноцепочечных полиненасыщенных жирных кислот. Отъем поросят от свиноматок приводит к нарушению метаболизма липидов в их организме, о чем свидетельствуют изменения жирнокислотного состава липидов в лимфоцитах крови поросят. В то же время, применение комплексного липосомального препарата вызывает корректирующеее влияние на содержание отдельных классов липидов ижирнокислотный спектр лимфоцитов крови поросят в условиях их отъема от свиноматок.

\section{Ключевые слова: ПОРОСЯТА, ОТЬЕМ, ЛИПОСОМАЛЬНЫЙ ПРЕПАРАТ, КЛАССЫ ЛИПИДОВ, ЖИРНОКИСЛОТНЫЙ СОСТАВ ЛИМФОЦИТОВ}

Lymphocytes are characterized by the specific lipids composition which determines their functional activity. Lipid compounds of cells are responsive indicators of processes that occur in the organism, and on the other hand the changes of the portion of structural lipids and the switch of energy metabolism from the breakdown of carbohydrates to lipids is an important indicator of violations of different species [1].

The weaning is accompanied by changes in energy metabolism, activating free radical oxidation and damage to biological membranes. The use of vitamin and mineral drugs has adjusting effect on metabolic processes, but their effect is too short and requires repeated injections. The liposomal drugs which under certain conditions can be absorbed by cells to fuse with cell membranes (that leads to the direct transport of liposome contents into the cell) are characterized of high therapeutic effect [2]. Encapsulation of active ingredients into liposome can modify their release and increases the bioavailability of such drugs. Therefore, the use of fat-soluble vitamins and mineral elements in the form of liposomal emulsions could be an important alternative for existing drugs and significantly improve their performance. 


\section{Materials and methods}

Experiments were carried out on two groups of counterpart piglets of Large white breed. Piglets of control group to 2 days before weaning where injected with isotonic sodium chloride, and experimental groups - «Vitarmin» drug [3]. Intramuscular injection was made once at a dose of $0.1 \mathrm{ml} / \mathrm{kg}$ of body weight. The material for the research were lymphocytes isolated from stabilized by heparin blood taken from the cranial vena cava of piglets 2 days before and on the $1^{\text {st }}, 5^{\text {th }}$ and $10^{\text {th }}$ day after weaning. Individual classes of lipids were determined by thin layer chromatography on silica gel [4]. Fatty acid composition of lymphocytes was determined by capillary gas-liquid chromatography [5] on the gas chromatograph Hewlett Packard HP-6890. Statistical analysis of the results was performed using the Microsoft Excel application.

\section{Results and discussion}

The data in Table 1 suggest that the weaning of piglets has no significant effect on the content of total lipids of lymphocytes. However, the increase of content of phospholipids on the $10^{\text {th }}$ day after weaning $(\mathrm{P}<0.05)$ and reduce $(\mathrm{P}<0.01)$ of content of non-esterified fatty acids (NEFA) have been shown. These results may show the adaptive reaction of piglets after weaning to the elevation of processes of lipid peroxidation (LPO) that reveal damaging effect on the phospholipids of cell membranes of lymphocytes.

Reduction of NEFA suggests the evidence of their increased utilization as an energy source in the face of considerable energy failure that occurs in the organism of piglets during weaning. Thus, in piglets of experimental group lymphocytes were observed tend of the increase of cholesterol accompanied with the decrease of triacylglycerols. Reduction in lymphocytes of piglets after weaning of triacylglycerol content that belong to the reserve lipids leads to the release and subsequent oxidation of fatty acids.

Introduction of «Vitarmin» drug to piglets caused increase of phospholipids content in the lymphocytes. On the $5^{\text {th }}$ day after weaning the differences were also reliable. Higher content of phospholipids in the lymphocytes of piglets lead to higher reactivity of immune cells because changes in their lipid composition accompany with the inductive phase of the immune response. Probably, the resulting effect is caused by the presence in the liposomal drug vitamin $\mathrm{A}, \mathrm{D}_{3}$ and $\mathrm{E}$. It is known that vitamin $\mathrm{A}$ stimulates the synthesis of phospholipids and

Table 1

The content of total lipids and its separated classes in piglets lymphocytes $(M \pm m, n=3-4)$

\begin{tabular}{|c|c|c|c|c|c|}
\hline \multirow{3}{*}{ Indices } & \multirow{3}{*}{$\begin{array}{l}\text { Groups of } \\
\text { animals }\end{array}$} & \multicolumn{4}{|c|}{ Periods of investigation } \\
\hline & & \multirow{2}{*}{$\begin{array}{l}\text { Day } 2 \text { before } \\
\text { the weaning }\end{array}$} & \multicolumn{3}{|c|}{ After weaning } \\
\hline & & & Day 1 & Day 5 & Day 10 \\
\hline \multirow{2}{*}{ Total lipids, g/l } & control & \multirow{2}{*}{$3.00 \pm 0.38$} & $3.07 \pm 0.17$ & $3.23 \pm 0.09$ & $3.23 \pm 0.23$ \\
\hline & experiment & & $3.23 \pm 0.07$ & $3.13 \pm 0.09$ & $3.27 \pm 0.07$ \\
\hline \multicolumn{6}{|c|}{ Individual classes, $\%$} \\
\hline \multirow{2}{*}{ Phospholipids } & control & \multirow{2}{*}{$13.89 \pm 1.71$} & $13.74 \pm 1.39$ & $12.96 \pm 1.32$ & $21.10 \pm 0.29^{\circ}$ \\
\hline & experiment & & $14.84 \pm 1.18$ & $20.67 \pm 1.38 *$ & $21.68 \pm 1.67$ \\
\hline \multirow{2}{*}{ Free cholesterol } & control & \multirow{2}{*}{$12.63 \pm 2.04$} & $15.45 \pm 0.76$ & $19.81 \pm 2.80$ & $18.71 \pm 1.31$ \\
\hline & experiment & & $16.12 \pm 2.01$ & $13.98 \pm 1.11$ & $20.39 \pm 1.56$ \\
\hline \multirow{2}{*}{ NEFA } & control & \multirow{2}{*}{$20.96 \pm 1.95$} & $16.01 \pm 0.46$ & $14.86 \pm 1.57$ & $9.47 \pm 1.36^{\circ \circ}$ \\
\hline & experiment & & $16.68 \pm 1.11$ & $13.32 \pm 1.87$ & $9.66 \pm 0.86$ \\
\hline \multirow{2}{*}{ Triacylglycerols } & control & \multirow{2}{*}{$24.54 \pm 0.76$} & $23.06 \pm 1.88$ & $24.12 \pm 2.03$ & $20.15 \pm 3.48$ \\
\hline & experiment & & $20.69 \pm 0.63$ & $24.39 \pm 1.23$ & $20.18 \pm 1.53$ \\
\hline \multirow{2}{*}{ Cholesterol esters } & control & \multirow{2}{*}{$27.97 \pm 3.57$} & $31.73 \pm 0.81$ & $28.20 \pm 1.78$ & $30.57 \pm 1.09$ \\
\hline & experiment & & $31.67 \pm 3.13$ & $27.63 \pm 1.69$ & $28.09 \pm 1.55$ \\
\hline
\end{tabular}

Note: Reliable differences regarding control group: *- $\mathrm{P}<0.05, * *-\mathrm{P}<0.01, * * * \ldots \mathrm{P}<0.001$; relation to the period before weaning: ${ }^{\circ}-\mathrm{P}<0.05,{ }^{\circ}-\mathrm{P}<0.01,{ }^{\circ}{ }^{\circ}-\mathrm{P}<0.001$ 
the antioxidant vitamin E shows the effect on the phospholipids of cell membranes protecting the polyunsaturated fatty acids from peroxidation [6]. Cholecalciferol is involved to the regulation of lipid metabolism and promotes the synthesis of phospholipids [7].

The weaning of piglets leads to a significant increase of content of palmitic acid and decrease of stearic acid content on the 1st day whereas the content was decreased in the lymphocytes of piglets of control group on the 5 th day after weaning (Table. 2). However, the content of palmitooleic acid in the lymphocytes of piglets of control group after weaning in comparison with to the period before weaning was increased $(\mathrm{P}<0.001)$, and oleic contrary - decreased $(\mathrm{P}<0.001)$. Studies have shown the reduction $(\mathrm{P}<0.001)$ of the content of arachidonic and begenic fatty acids in the lymphocytes of piglets of control group after weaning.

The changes of fatty acid lipid profile of weaned piglets' lymphocytes in the control group were characterized by increasing the total value of saturated acids and decreasing of unsaturated acids compared the period before weaning. The reduction of unsaturated of fatty acids in the control group of weaned piglets was due to a possible decrease of monoenoic acids, including oleic, eicosenoic and nervonic acids. The studies have shown the multi-vector changes in the control group of weaned piglets such as changes of eicosapolyenoic acids, in particular, the growth of content of eicosadienoic $(\mathrm{P}<0.05)$ and linoleic acid $(\mathrm{P}<0.001)$ and reduction of arachidonic $(\mathrm{P}<0.01)$ and eicosapentaenoic acids $(\mathrm{P}<0.001)$. On the $1^{\text {st }}$ day after weaning piglets, the increase $(\mathrm{P}<0.01)$ and, on the $5^{\text {th }}$ day, the reduction $(\mathrm{P}<0.001)$ in the lymphocytes of piglets the content of $\alpha$-linolenic acid have been detected. Reduction of arachidonic acid may indicate its release from lymphocytes which increased with its subsequent conversion into lipoxygenase and cyclooxygenase metabolic cascade pathways. Reducing the amount of polyunsaturated fatty acids in the lipid composition of lymphocytes in the blood of piglets of control group can be explained by their excessive involvement in the process of lipid peroxidation.
The research has found no significant changes in the ratio of fatty acids in the lymphocytes of piglets in the experimental group on the $1^{\text {st }}$ day after weaning that indicates a stabilizing effect of liposomal components of the drug on lipid metabolism in the organism of weaned piglets.

Administration to piglets the drug «Vitarmin» causes reduction of palmitic $(\mathrm{P}<0.001)$ and stearic $(\mathrm{P}<0.01)$ fatty acids on the $5^{\text {th }}$ day after weaning. In piglets lymphocytes the trend to increase of palmitooleic and oleic fatty acids content has been observed. In the lymphocytes of piglets, trend of increase of palmitooleic and oleic fatty acids content was observed.

Among the polyunsaturated fatty acids the highest level of unsaturation found in the lymphocytes of piglets of experimental group on the $5^{\text {th }}$ day after weaning. Thus, at this period, the increasing of $\alpha$-linolenic $(\mathrm{P}<0.05)$, arachidonic $(\mathrm{P}<0.001)$ and docosahexaenoic $(\mathrm{P}<0.05)$ acids has been shown. In the lymphocytes of experimental group piglets, high level of docosahexaenoic acid accompanied with a tendency to increase of the eicosapentaenoic acid content can lead to a reduction of pro-inflammatory eicosanoids and cytokines [8]. Increased fatty acid unsaturation suggests higher adaptive capacity of animals to environmental conditions. Vitamin $\mathrm{D}_{3}$ influences the growth the phospholipids content of arachidonic, docosapentaenoic and docosahexaenoic acids. Vitamin A and carotenoids affect the composition of the cell membranes and levels of docosahexaenoic and docosapentaenoic fatty acids [9]. Zinc increases the activity of enzymes of system of elongation and desaturation of fatty acids [10].

The increase of total number of unsaturated fatty acids accompanied with decreasing amount of saturated fatty acids has been observed in the lymphocytes of blood of piglets of experimental group after weaning. This effect may be due to the effect of liposomal drug consisting of antioxidants that decrease the degree of peroxidation of polyunsaturated fatty acids.

\section{Conclusions}

It has been established that the weaning of piglets leads to changes of lipid metabo- 
Fatty acid profile of lymphocytes in piglets blood $(M \pm m, n=3-4)$

\begin{tabular}{|c|c|c|c|c|}
\hline \multirow{3}{*}{ Indices } & \multirow{3}{*}{$\begin{array}{c}\text { Groups } \\
\text { of animals }\end{array}$} & \multicolumn{3}{|c|}{ Periods of investigation } \\
\hline & & \multirow{2}{*}{$\begin{array}{l}\text { Day } 2 \text { before the } \\
\text { weaning }\end{array}$} & \multicolumn{2}{|c|}{ After weaning } \\
\hline & & & Day 1 & Day 5 \\
\hline \multirow{2}{*}{ Miristic, 14:0 } & control & \multirow{2}{*}{$0.601 \pm 0.089$} & $0.688 \pm 0.012$ & $0.622 \pm 0.041$ \\
\hline & experiment & & $0.628 \pm 0.005 * *$ & $0.594 \pm 0.084$ \\
\hline \multirow{2}{*}{ Palmitic, 16:0 } & control & \multirow{2}{*}{$16.382 \pm 0.108$} & $24.037 \pm 0.257^{\circ 0 \circ}$ & $23.249 \pm 0.069^{\circ \circ \circ}$ \\
\hline & experiment & & $23.444 \pm 0.282$ & $16.983 \pm 0.623 * * *$ \\
\hline \multirow{2}{*}{ Palmitooleic, 16:1 } & control & \multirow{2}{*}{$0.434 \pm 0.009$} & $0.984 \pm 0.009^{\circ \circ \circ}$ & $0.952 \pm 0.003^{\circ 0 \circ}$ \\
\hline & experiment & & $0.973 \pm 0.007$ & $1.020 \pm 0.241$ \\
\hline \multirow{2}{*}{ Stearic, 18:0 } & control & \multirow{2}{*}{$3.117 \pm 0.019$} & $1.105 \pm 0.033^{\circ 0 \circ}$ & $4.329 \pm 0.010^{\circ 0 \circ}$ \\
\hline & experiment & & $1.141 \pm 0.068$ & $1.021 \pm 0.522 * *$ \\
\hline \multirow{2}{*}{ Oleic, $18: 1$} & control & \multirow{2}{*}{$50.335 \pm 0.455$} & $44.394 \pm 0.647^{\circ 00}$ & $46.362 \pm 0.176^{\circ 0 \circ}$ \\
\hline & experiment & & $45.702 \pm 0.148$ & $49.915 \pm 5.127$ \\
\hline \multirow{2}{*}{ Linoleic, 18:2 } & control & \multirow{2}{*}{$15.332 \pm 0.156$} & $17.937 \pm 0.197^{\circ 0 \circ}$ & $17.324 \pm 0.088^{\circ 00}$ \\
\hline & experiment & & $17.601 \pm 0.155$ & $15.528 \pm 1.258$ \\
\hline \multirow{2}{*}{$\gamma$-Linolenic, 18:3 } & control & \multirow{2}{*}{$0.318 \pm 0.057$} & $0.387 \pm 0.026$ & $0.309 \pm 0.019$ \\
\hline & experiment & & $0.330 \pm 0.001$ & $0.424 \pm 0.123$ \\
\hline \multirow{2}{*}{$\alpha$-Linolenic, $18: 3$} & control & \multirow{2}{*}{$3.193 \pm 0.240$} & $4.474 \pm 0.059^{\circ \circ}$ & $1.139 \pm 0.037^{\circ 00}$ \\
\hline & experiment & & $4.354 \pm 0.054$ & $5.443 \pm 1.044^{*}$ \\
\hline \multirow{2}{*}{ Arachinic, 20:0 } & control & \multirow{2}{*}{$1.110 \pm 0.004$} & $0.947 \pm 0.014^{\circ 00}$ & $0.913 \pm 0.002^{\circ \circ \circ}$ \\
\hline & experiment & & $0.927 \pm 0.011$ & $0.992 \pm 0.165$ \\
\hline \multirow{2}{*}{ Eicosenoic, 20:1 } & control & $0407+0.004$ & $0.489 \pm 0.001$ & $0.467 \pm 0.001^{\circ \circ \circ}$ \\
\hline & experiment & $0.49 / \pm 0.004$ & $0.479 \pm 0.016$ & $0.464 \pm 0.037$ \\
\hline Ficosadianois 20.2 & control & $0278+0.027$ & $0.506 \pm 0.021^{\circ}$ & $0.509 \pm 0.020^{\circ}$ \\
\hline Eicosadienoic, 20:2 & experiment & $0.3 / 8 \pm 0.022$ & $0.496 \pm 0.001$ & $0.408 \pm 0.048$ \\
\hline Ficosatrianois 20.3 & control & $0738+0078$ & - & - \\
\hline Eicosatrienoic, 20:3 & experiment & $0.138 \pm 0.028$ & - & - \\
\hline A rashidonis 20.4 & control & $0762+0.091$ & $0.328 \pm 0.002^{\circ \circ}$ & $0.289 \pm 0.006^{\circ \circ}$ \\
\hline Aracnidonic, 2U:4 & experiment & $0.102 \pm 0.091$ & $0.385 \pm 0.062$ & $1.684 \pm 0.086 * * *$ \\
\hline Cipos 20.5 & control & $0704+0.025$ & $0.260 \pm 0.011^{\circ 0 \circ}$ & $0.240 \pm 0.007^{\circ 00}$ \\
\hline Eicosapentaenoic, 20:5 & experiment & $0.104 \pm 0.035$ & $0.315 \pm 0.023$ & $0.505 \pm 0.123$ \\
\hline Poronis 22.0 & control & $1610+0050$ & $0.952 \pm 0.010^{\circ 0 \circ}$ & $0.919 \pm 0.002^{\circ \circ \circ}$ \\
\hline Begenic, 2L:0 & experiment & $1.019 \pm 0.059$ & $0.926 \pm 0.004$ & $0.922 \pm 0.097$ \\
\hline Docsanentranais 22.5 & control & $0002+0177$ & $0.994 \pm 0.173$ & $0.962 \pm 0.023$ \\
\hline Docosapentaenoic, $22: 5$ & experiment & $0.992 \pm 0.1 / 7$ & $0.616 \pm 0.001$ & $1.671 \pm 0.265$ \\
\hline Docosoheynenois 22.6 & control & $1231+0.046$ & $0.261 \pm 0.004^{\circ 00}$ & $0.253 \pm 0.009^{\circ 00}$ \\
\hline Docosahexaeno1c, $22: 6$ & experiment & $1.231 \pm 0.046$ & $0.529 \pm 0.129$ & $1.477 \pm 0.329^{*}$ \\
\hline Jignocoris 21.0 & control & $0001+0008$ & $0.798 \pm 0.115$ & $0.801 \pm 0.055$ \\
\hline Lignoceric, 24:0 & experiment & $0.991 \pm 0.098$ & $0.749 \pm 0.117$ & $0.631 \pm 0.281$ \\
\hline Naryonis $21 \cdot 1$ & control & $0716+0023$ & $0.320 \pm 0.002^{\circ 00}$ & $0.326 \pm 0.019^{\circ 00}$ \\
\hline Nervonic, 24:1 & experiment & $0.716 \pm 0.023$ & $0.414 \pm 0.002 * * *$ & $0.875 \pm 0.098 * *$ \\
\hline & control & 2202 & 28.53 & 30.83 \\
\hline$\sum$ saturated & experiment & 23.82 & 27.82 & 21.15 \\
\hline & control & & 71.34 & 69.13 \\
\hline ted & experiment & 75.63 & 72.20 & 79.41 \\
\hline
\end{tabular}

lism in their body as evidenced by an increase of phospholipids and decrease the content of NEFA in the lymphocytes on the $10^{\text {th }}$ day after weaning.

Introduction of drug «Vitarmin» to piglets two days before weaning reliably contrib- 
acids as arachidonic, docosahexaenoic and docosapentaenoic acids.

Perspectives of future research. It is reasonable to study the influence of this immunotropic liposomal drug on the performance of antioxidant and nitrogen oxide system as well as mineral metabolism in the organism of piglets.

1. Lymarev V. A Features of disorganization of the lipid and phospholipid components of membranes of lymphocytes in the combined course of chronic obstructive lung disease and anemia in patients who had undergone pulmonary tuberculosis. Ukr. Med. Almanac, 2010, vol. 13, no 1, pp. 72-74. (in Ukrainian)

2. Galkin O. Yu., Bondarenko L. B., Dugan O. M. Biotechnological approaches to the creation and use of liposomal and pegley dosage forms. Naukovi Visti $N T U U$ «KPI», 2009, no 3, pp. 88-93. (in Ukrainian).

3. Ohorodnyk N. Z., Kychun I. V., Vischur O. I. Application for utility model, No U201501800. Vitamin and mineral drug with prolonged action «Vitarmin». From 02.03.2015. (in Ukrainian)

4. Kates M. Techniques of lipidology. Amsterdam : Elsevier, 1986, 451 p. (in Russian)
5. Holubec O. V., Vudmaska I. V. Definition of lipid fatty acid composition by capillary gas-liquid chromatography. Method. recommendations. Lviv, 2010, 37 p. (in Ukrainian)

6. Sanyal A., Chalasani N., Kowdley K. Pioglitazone, vitamin E, or placebo for nonalcoholic steatohepatitis. N. Engl. J. Med. 2010, vol. 362, no 18, pp. 1675-1685.

7. Wacker M., Holick M. Vitamin D - effects on skeletal and extraskeletal health and the need for supplementation. Nutrients. 2013, vol. 5, no 1, pp. 111-148.

8. Pan H. C., Kao T. K., Ou Y. C. Protective effect of docosahexaenoic acid against brain injury in ischemic rats. J. Nutr. Biochem. 2009, vol. 20, pp. 715-725.

9. Duh A. I., Vovk S. Changes of lipid content and fatty acid composition of yolk in eggs and liver breeding chickens and embryos depending on the level of carotenoids in the diet. Ukr. Biochem. Zh. 2010, vol. 82, no 5, pp 118-124. (in Ukrainian)

10. Korniluk K., Gabryszuk M., Kowalczyk J., Czauderna M. Effect of diet supplementation with selenium, zinc and $\alpha$-tocopherol on fatty acid composition in the liver and loin muscle of lambs. Anim. Sci. Pap. and Rep. 2008, vol. 26, no 1, pp. 59-70. 